\title{
Full Reversal of Alzheimer's Disease-Like Phenotype in a Mouse Model with Conditional Overexpression of Glycogen Synthase Kinase-3
}

\author{
Tobias Engel, Félix Hernández, Jesús Avila, and José J. Lucas \\ Centro de Biología Molecular "Severo Ochoa," Consejo Superior de Investigaciones Científicas/Universidad Autónoma de Madrid, 28049 Madrid, Spain
}

\begin{abstract}
Glycogen synthase kinase-3 (GSK-3) is a ubiquitously expressed serine/threonine kinase that is particularly abundant in the CNS. Dysregulation of GSK-3 activity is believed to play a key role in the pathogenesis of CNS chronic disorders such as Alzheimer's disease (AD), bipolar disorder, and Huntington's disease, and of metabolic disorders such as type II diabetes. Accordingly, GSK-3 inhibitors have been postulated as therapeutic tools for these diseases. Interestingly, pathophysiological and pharmacological regulation of GSK-3 is affected by an amplification mechanism that applies both to inhibition and activation. The possibility therefore exists that sustained inhibition or activation might persist after cessation of the initial trigger. Regarding AD, GSK-3 has been shown to accumulate in pretangle neurons. Furthermore, GSK-3 phosphorylates tau in most serine and threonine residues hyperphosphorylated in PHF (paired helical filament)-tau and GSK-3 activity contributes both to $\beta$-amyloid production and to $\beta$-amyloid-mediated neuronal death. In good agreement, mice with conditional overexpression of GSK-3 in forebrain neurons (Tet/GSK-3 $\beta$ mice) recapitulate aspects of AD neuropathology such as tau hyperphosphorylation, apoptotic neuronal death, and reactive astrocytosis as well as spatial learning deficit. Here, we exploit the conditional system used to generate Tet/GSK-3 $\beta$ mice to explore whether the biochemical, histopathological, and behavioral consequences of increased GSK-3 activity are susceptible to revert after restoration of normal GSK-3 levels. Here, we show that transgene shutdown in symptomatic mice leads to normal GSK-3 activity, normal phospho-tau levels, diminished neuronal death, and suppression of the cognitive deficit, thus further supporting the potential of GSK-3 inhibitors for AD therapeutics.
\end{abstract}

Key words: GSK-3; Alzheimer's disease; reversal; conditional mouse model; tau; apoptosis; object recognition task

\section{Introduction}

Glycogen synthase kinase-3 (GSK-3) is a ubiquitously expressed serine/threonine kinase that is particularly abundant in the CNS (Woodgett, 1990). GSK-3 is known to participate in multiple signaling pathways coupled to receptors for a variety of signaling molecules such as insulin or wnt among many others (Jope and Johnson, 2004). GSK-3 phosphorylation substrates include cytoskeletal proteins, transcription factors, and metabolic regulators, thus leading to a prominent role of GSK-3 in cellular architecture, gene expression, and apoptosis among others (Jope and Johnson, 2004).

Dysregulation of GSK-3 activity is believed to play a key role in the pathogenesis of chronic disorders of the CNS such as Alzheimer's disease $(\mathrm{AD})$, bipolar disorder, and Huntington's disease (Avila et al., 2004; Jope and Johnson, 2004), as well as of meta-

Received Dec. 12, 2005; accepted March 12, 2006.

This work was supported by grants from Comunidad de Madrid, Fundación "La Caixa," and the Spanish Ministry of Science and by institutional grants from Fundación Ramón Areces and from Fondo de Investigaciones Sanitarias. We thank Drs. Javier Díaz-Nido, Ana Martínez, Miguel Medina, Francisco Moreno, and Francisco Wandosell for helpful discussion and comments, and Dr. Peter Davies for kindly providing the PHF-1 antibody. We are also grateful to Javier Palacín, Raquel Cuadros, and Elena Langa for technical assistance.

Correspondence should be addressed to José J. Lucas, Centro de Biología Molecular "Severo Ochoa," Consejo Superior de Investigaciones Científicas/Universidad Autónoma de Madrid, Facultad de Ciencias, Universidad Autónoma de Madrid, Cantoblanco, 28049 Madrid, Spain. E-mail: jjlucas@cbm.uam.es.

DOI:10.1523/JNEUROSCI.0604-06.2006

Copyright $\odot 2006$ Society for Neuroscience $\quad$ 0270-6474/06/265083-08\$15.00/0 bolic disorders such as type II diabetes (Eldar-Finkelman, 2002). In AD, GSK-3 has been shown to phosphorylate tau in most of the serine and threonine residues that are hyperphosphorylated in paired helical filament (PHF)-tau both in cells (Lovestone et al., 1994) and in vivo (Hong et al., 1997; Munoz-Montano et al., 1997; Spittaels et al., 2000; Lucas et al., 2001) and to accumulate in the cytoplasm of pretangle neurons (Shiurba et al., 1996; Pei et al., 1999). The GSK-3 $\beta$ isoform has been shown to bind presenilin-1 (PS-1) and mutant PS-1 expression increases GSK-3 activity and tau phosphorylation in cells (Takashima et al., 1998; Zhang et al., 1998). GSK-3 activity has been shown to mediate $\beta$-amyloid $(\mathrm{A} \beta)$ production from its precursor APP (amyloid precursor protein) (Sun et al., 2002; Phiel et al., 2003; Ryder et al., 2003 ), and $\mathrm{A} \beta$-mediated toxicity to cultured neurons depends on increased GSK-3 activity (Takashima et al., 1993, 1996; Busciglio et al., 1995; Ferreira et al., 1997; Alvarez et al., 1999).

In view of the evidence linking increased GSK-3 activity and $\mathrm{AD}$ pathogenesis, GSK-3 inhibitors have been postulated to be a good therapeutic tool for AD. Accordingly, potent and specific GSK-3 inhibitors are currently under development (Cohen and Goedert, 2004). However, physiological regulation of GSK-3 activity is a complex issue. GSK-3 activity has been shown to be modulated by phosphorylation, subcellular localization, protein complex formation, and priming phosphorylation of substrates. Furthermore, an amplification mechanism that affects both inhi- 
bition (Jope, 2003; Zhang et al., 2003) and activation (Szatmari et al., 2005) of GSK-3 has been reported. It is, therefore, possible that in vivo sustained inhibitions or activations might persist after cessation of the initial trigger.

We have previously generated mice with forebrain overexpression of GSK-3 $\beta$ (Tet/GSK-3 $\beta$ mice) that recapitulate many aspects of the neuropathology such as tau hyperphosphorylation, reactive astrocytosis, and neuronal death (Lucas et al., 2001) as well as spatial learning deficit (Hernandez et al., 2002). Because transgene expression in Tet/GSK- $3 \beta$ mice is conditional by the use of the Tet-off system, we were able to test whether biochemical, histopathological, and behavioral consequences of elevated GSK-3 are susceptible to revert after restoration of normal GSK-3 activity (as an ideal inhibitor might do). Here, we show that shutdown of GSK-3 $\beta$ overexpression leads to normal GSK-3 activity, normal phospho-tau levels, diminished neuronal death, and suppression of the cognitive deficit, thus further supporting the potential of GSK-3 inhibitors in the treatment of AD.

\section{Materials and Methods}

Animals. Mice were bred at the Centro de Biología Molecular "Severo Ochoa" animal facility. Mice were housed four per cage with food and water available ad libitum and maintained in a temperature-controlled environment on a 12/12 h light/dark cycle with light onset at 7 A.M. Tet/GSK-3 $\beta$ mice were generated as previously described (Lucas et al., 2001). Briefly, Tet/GSK-3 $\beta$ mice result from the breeding of TetO mice (carrying the bidirectional tet responsive promoter followed by GSK-3 $\beta$ and $\beta$-galactosidase cDNAs, one in each direction) with CaMKII $\alpha$-tTA mice. The Tet/GSK- $3 \beta$ mice overexpress GSK- $3 \beta$ in cortical and hippocampal neurons in a conditional manner repressible by the administration of tetracycline or its analog doxycycline.

Doxycycline treatment. Tet/GSK-3 $\beta$ and its control littermates were given doxycycline ( $2 \mathrm{mg} / \mathrm{ml}$; Sigma, St. Louis, MO) in drinking water ad libitum during 6 weeks starting at the age of 4 weeks.

Antibodies. The following anti-tau antibodies were used: PHF-1 (Greenberg et al., 1992; Otvos et al., 1994) (a kind gift from Dr. Peter Davies, Albert Einstein College of Medicine, New York, NY), AD2 (BueeScherrer et al., 1996) (Bio-Rad, Hercules, CA), glial fibrillary acidic protein (GFAP) (PharMingen, San Diego, CA), AT-8 (Biernat et al., 1992; Mercken et al., 1992) (Innogenetics, Gent, Belgium), cleaved caspase-3 (Cell Signaling Technology, Beverly, MA), anti-GSK- $3 \alpha / \beta$ (Biosource, Camarillo, CA), anti-myc (Developmental Studies Hybridoma Bank, Iowa City, IA), and anti- $\beta$-tubulin (Sigma). According to the residue numbering of the longest human tau isoform of 441 aa, antibody PHF-1 and AD2 can react with tau when serines 396 and 404 are phosphorylated (Buee-Scherrer et al., 1996), although it has also been reported that the presence of phosphorylated Ser396 in tau protein appears to be sufficient for $\mathrm{AD} 2$ recognition and that phosphorylation in Ser404 seems not to play a major role in this binding (Torreilles et al., 2000) and the AT-8 antibody recognizes tau when Ser202 and Thr205 are phosphorylated (Goedert et al., 1995). The 7.51 antibody recognizes segments of the last two repeats within the microtubule binding domain of tau in a phosphorylation-independent manner (Novak et al., 1991) and detects all soluble tau isoforms in Western blot analysis and unbound tau in immunohistochemical analysis.

Object recognition task. Only male mice were used for this test. Mice were tested at the ages of 4 and 10 weeks (10-16 mice per group). The object recognition task was performed essentially as described previously (Ennaceur et al., 1997; Woolley et al., 2003). Briefly, the mice were habituated for $30 \mathrm{~min}$ to a plastic box with vertical opaque walls $(73 \times 33 \times$ $25 \mathrm{~cm}$ ) on the first day. On the second day, the animals were placed in the same box for $10 \mathrm{~min}$ without any object. Then, $2 \mathrm{~h}$ later, each mouse was released on the open field for $4 \mathrm{~min}$ in the absence of any object. Then, it was removed from the trial cage and placed in its home cage for $1 \mathrm{~min}$. Familiarization trial was then performed for $5 \mathrm{~min}$, allowing them to explore the two identical objects (objects $\mathrm{A}$ and $\mathrm{B}$ ). The two objects were placed along the long axis of the cage, each $7 \mathrm{~cm}$ from each cage end. After each exposure, the objects and the cage were wiped with 70\% ethanol to eliminate odor clues. Two hours after the familiarization trail, each mouse was released on the open field with one of the old objects (object A) and a new one (object $C$ ). The position of object $C$ was the same as object $\mathrm{B}$ in the familiarization trail, and the time to recognize them was again $5 \mathrm{~min}$. Animals were considered to show recognition activity when the head of the animal was $<2 \mathrm{~cm}$ close to the object. The time $\left(t_{\mathrm{A}}\right.$ and $\left.t_{\mathrm{C}}\right)$ the animal spent exploring the two objects (objects A and C) was recorded. The memory index (MI), defined as the ratio of the time spent exploring the novel object over the time spent exploring both objects, $\mathrm{MI}=\left[t_{\mathrm{C}} /\left(t_{\mathrm{A}}+t_{\mathrm{C}}\right)\right] \times 100$, was used to measure nonspatial memory. Statistical analysis was performed using Student's $t$ test in those results shown in Figure 1 and by ANOVA followed by a post hoc test in those results shown in Figure 6.

GSK-3 activity assay. Hippocampal tissue was homogenated in $20 \mathrm{~mm}$ HEPES, pH 7.4, $100 \mathrm{~mm} \mathrm{NaCl}, 10 \mathrm{~mm} \mathrm{NaF}, 1 \mathrm{~mm} \mathrm{VO} \mathrm{VNa}_{4}$, Triton X-100, 1 mм EDTA, 1 mм EGTA, and a mixture of peptidase inhibitors (Roche, Basel, Switzerland). Homogenates were centrifuged at 14,000 $\times$ $g$ for $15 \mathrm{~min}$ and supernatants were collected for GSK-3 activity assays. The GS1 peptide (YRRAAVPPSPSLSRHSSPHQS ${ }^{\star}$ EDEE) containing Ser21 in phosphorylated form was used as substrate (Stambolic and Woodgett, 1994). Supernatants were incubated at $37^{\circ} \mathrm{C}$ with $30 \mu \mathrm{M} \mathrm{GS1}$ peptide in the presence of $50 \mu \mathrm{M}\left[\gamma_{-}{ }^{32} \mathrm{P}\right]$ ATP (DuPont NEN, Boston, MA) in $25 \mathrm{~mm}$ Tris, pH 7.5, $1 \mathrm{~mm}$ DTT, $10 \mathrm{~mm} \mathrm{MgCl}_{2}$, and either $10 \mathrm{~mm}$ $\mathrm{NaCl}$ or $10 \mathrm{~mm} \mathrm{LiCl}$. The assays were stopped by spotting aliquots on $\mathrm{P} 81$ phosphocellulose paper. Filters were processed as described previously (Moreno et al., 1996). GSK-3 activity was calculated as the difference between the activity in the presence of $10 \mathrm{~mm} \mathrm{NaCl}$ and the activity in the presence of $10 \mathrm{~mm} \mathrm{LiCl}$. Results correspond to four mice per group and were expressed as a percentage with respect to activity levels in extracts from wild-type mice receiving water. Statistical analysis was determined by ANOVA followed by a post hoc test.

Immunohistochemistry. Mice were anesthetized with a xylazine/ketamine solution and transcardially perfused with $4 \%$ paraformaldehyde (PFA) in Sorensen's buffer for 10 min. Brains were postfixed in $4 \%$ PFA for $2 \mathrm{~h}$ at $4^{\circ} \mathrm{C}$ and cryoprotected in $30 \%$ sucrose solution. Thirtymicrometer sagittal sections were cut on a freezing microtome (Leica, Nussloch, Germany) and collected in $0.1 \%$ azide-PBS solution. Next, brain sections were pretreated for $1 \mathrm{~h}$ with $1 \%$ BSA, 5\% FBS, and $0.2 \%$ Triton X-100, and then incubated with primary antibodies at the following dilutions: PHF-1 (1/150), anti-GFAP (1/1000), caspase-3 (1/50), anti-Myc (1/10), and 7.51 (1/200). Finally, brain sections were incubated in avidin-biotin complex using the Elite Vectastain kit (Vector Laboratories, Burlingame, CA). Chromogen reactions were performed with diaminobenzidine (Sigma) and $0.003 \% \mathrm{H}_{2} \mathrm{O}_{2}$ for $10 \mathrm{~min}$. Sections were coverslipped with Fluorosave. Results correspond to six mice per group except for caspase-3 $(n=8)$ and were expressed as mean \pm SEM of the number of immunopositive neurons in dentate gyrus of $30 \mu \mathrm{m}$ hippocampal sagittal sections [matching Fig. 114 of Paxinos and Franklin (2001)] at $1.56 \mathrm{~mm}$ with respect to the midline. Statistical analysis was determined by ANOVA followed by a post hoc test.

Western blot analysis. Brains were quickly dissected on an ice-cold plate. Extracts for Western blot analysis were prepared by homogenizing the brain areas in ice-cold extraction buffer consisting of $20 \mathrm{~mm}$ HEPES, pH 7.4, $100 \mathrm{~mm} \mathrm{NaCl}, 20 \mathrm{~mm} \mathrm{NaF}, 1 \%$ Triton X-100, 1 mm sodium orthovanadate, $5 \mathrm{~mm}$ EDTA, and protease inhibitors (2 mм PMSF, 10 $\mu \mathrm{g} / \mathrm{ml}$ aprotinin, $10 \mu \mathrm{g} / \mathrm{ml}$ leupeptin, and $10 \mu \mathrm{g} / \mathrm{ml}$ pepstatin). The samples were homogenized and centrifuged at $15,000 \times g$ for $20 \mathrm{~min}$ at $4^{\circ} \mathrm{C}$. The resulting supernatant was collected, and protein content was determined by Bradford. Thirty micrograms of total protein were electrophoresed on $10 \%$ SDS-polyacrylamide gel and transferred to a nitrocellulose membrane (Schleicher \& Schuell, Keene, NH). The experiments were performed using the following primary monoclonal antibodies: antiGSK-3 $\beta$ (1/1000), PHF-1 (1/200), AD2 (1/2000), AT8 (1/100), and anti$\beta$-tubulin (1/5000). The filters were incubated with the antibody at $4^{\circ} \mathrm{C}$ overnight in $5 \%$ nonfat dried milk. A secondary goat anti-mouse antibody (1/5000; Invitrogen, San Diego, CA) and ECL detection reagents (Amersham Biosciences, Arlington Heights, IL) were used for immunodetection. Quantification of GSK-3 $\beta$, PHF-1, AD2, and AT8 immunore- 
A

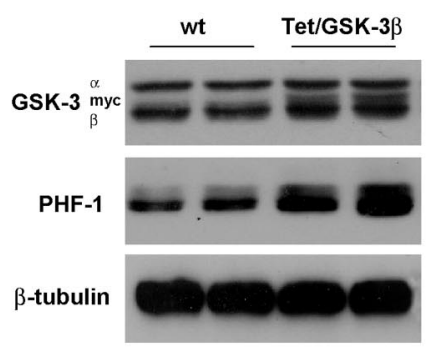

C

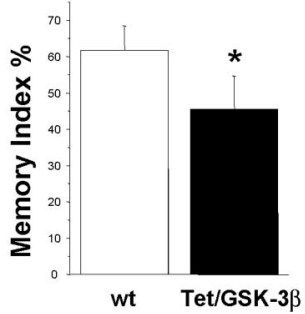

B

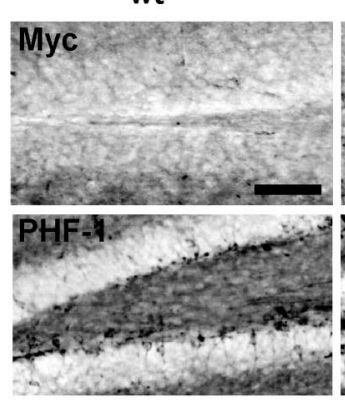

Tet/GSK-3ß
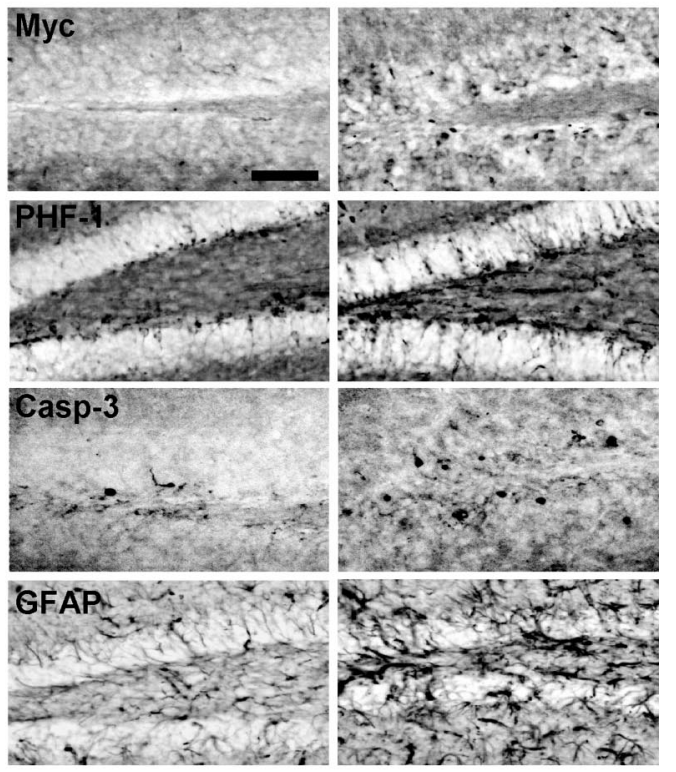

Figure 1. Tau hyperphosphorylation, apoptotic neuronal death, reactive gliosis, and learning deficit in Tet/GSK-3 $\beta$ mice. $\boldsymbol{A}$, Western blot analysis of hippocampal protein extracts from wild-type (wt) or Tet/GSK-3 $\beta$ mice probed with antibodies against GSK-3 $\alpha / \beta$ and AD-like phosphorylated tau (PHF-1). $\boldsymbol{B}$, Immunohistochemistry in hippocampal sections of wild-type (wt) and Tet/GSK-3 $\beta$ mice performed with the antibodies against transgenic GSK-3 $\beta$ (MYC), PHF-1, cleaved caspase-3 (Casp-3), and GFAP. C, Histogram showing the deficit in spatial memory of Tet/GSK-3 $\beta$ mice versus wild-type (wt) mice in the object recognition test. The memory index is expressed as exploratory preference in the retention test. Memory index $=\left[t_{\mathrm{C}} /\left(t_{\mathrm{A}}+t_{\mathrm{C}}\right)\right] \times 100$, with $\mathrm{A}$ and C representing the familiar and the novel objects, respectively. Error bars indicate SE. ${ }^{*} p 0.02$. Scale bar, $50 \mu \mathrm{m}$.

activities was performed by densitometric scanning. The densitometry values correspond to eight animals per group and were obtained in the linear range of detection with these antibodies. These values were normalized with respect to the values obtained with an anti- $\beta$-tubulin antibody to correct for any deviation in loaded amounts of protein or respect to the values obtained with 7.51 antibody to correct for total tau content. Statistical analysis was determined by ANOVA followed by a post hoc test.

Tubulin assembly assay. Temperature-dependent assembly of tubulin from mouse brain was performed by the procedure of Shelanski et al. (1973) with one polymerization cycle including $20 \%$ glycerol (Scheele and Borisy, 1976). Briefly, hippocampal homogenates was prepared in buffer A (0.5 mm $\mathrm{MgCl}_{2}$, 2.0 mm EGTA, 0.1 mm MES-NaOH buffer, pH 6.7) and centrifuged for $1 \mathrm{~h}$ at $40,000 \times g$. The supernatant with a protein concentration of $10 \mathrm{mg} / \mathrm{ml}$ was supplemented with $1 \mathrm{~mm}$ GTP and $20 \%$ glycerol and was incubated for $30 \mathrm{~min}$ at $37^{\circ} \mathrm{C}$. Polymerized protein was fractionated from unpolymerized protein by centrifugation for $10 \mathrm{~min}$ in a Beckman Airfuge at $25^{\circ} \mathrm{C}$. The polymerized protein as well as the supernatant was further analyzed by Western blot with the $\beta$-tubulin antibody. Results correspond to four mice per group and were expressed as mean \pm SEM of densitometry values in arbitrary units obtained in the linear range of detection. Statistical analysis was determined by ANOVA followed by a post hoc test.

\section{Results}

Six weeks of doxycycline treatment restores normal GSK-3 levels and activity in Tet/GSK-3 $\beta$ mice

We have previously shown increased GSK-3 levels and activity in hippocampus of Tet/GSK-3 mice (Lucas et al., 2001; Hernandez et al., 2002). This results in increased tau phosphorylation, apoptotic neuronal death, and reactive gliosis in hippocampus ( $\mathrm{Lu}-$ cas et al., 2001) and in a deficit in spatial learning (Hernandez et al., 2002). As shown in Figure 1A, the increase in GSK-3 levels and in tau phosphorylation is evident by Western blot by the age of 1 month. Also, in 1-month-old Tet/GSK- $3 \beta$ mice, it is possible to detect by immunohistochemistry the expression of Myc-tagged GSK-3, the resulting tau hyperphosphorylation, and an increased number of cleaved caspase-3positive neurons and reactive astrocytes (Fig. $1 B$ ). One-month-old Tet/GSK-3 $\beta$ mice also showed a learning deficit as evidenced in the object recognition test (Fig. $1 C)$. In this test, wild-type mice spent significantly more time recognizing the novel object, whereas Tet/GSK- $3 \beta$ mice failed to distinguish between the old and new object showing no preference for either object as can be seen by a memory index of $\sim 50 \%$.

We then decided to establish the minimal time of transgene silencing by administration of the tetracycline analog doxycycline $(2 \mathrm{mg} / \mathrm{ml}$ in the drinking water) that would result in full shutdown of transgenic GSK-3 $\beta$ expression in Tet/GSK-3 $\beta$ mice (Fig. 2). As shown in Figure $2 A, 4$ weeks of doxycycline treatment resulted in $\sim 70 \%$ decrease in transgenic GSK-3 $\beta$ levels. Interestingly, after 6 weeks of doxycycline administration, transgenic GSK- $3 \beta$ was no longer detected either by immunohistochemistry with an anti-Myc antibody (Fig. $2 B, C$ ) or by Western blot with an anti-GSK-3 antibody that recognizes both the endogenous GSK-3 isoforms and the transgenic Myc-tagged GSK-3 isoform (Fig. $2 A, D$ ). For the reversibility studies, we thus decided to treat Tet/GSK-3 $\beta$ mice for 6 weeks, and these mice will be hereafter named Gene-OFF Tet/GSK-3 $\beta$ mice.

As mentioned above, there is a mechanism for amplification of GSK-3 activation in neurons that may result in increased activity after cessation of the trigger of activation (Szatmari et al., 2005). We therefore tested whether GSK-3 activity returned to normal levels after full shutdown of transgenic GSK-3 expression. As shown in Figure 2 E, the full shutdown of the GSK-3 transgene obtained after 6 weeks of doxycycline treatment resulted in restoration of normal GSK-3 activity in hippocampal homogenates.

\section{Full reversal of AD-like tau hyperphosphorylation in Gene- OFF Tet/GSK-3 $\beta$ mice}

We then analyzed the effect of full shutdown of transgene expression on tau phosphorylation (Fig. 3). We have previously reported that Tet/GSK- $3 \beta$ mice show tau hyperphosphorylation at the phosphoepitopes recognized by the PHF-1 and AD2 antibodies (Lucas et al., 2001). However, Gene-OFF Tet/GSK-3 $\beta$ mice no longer showed increased tau phosphorylation at the PHF-1 epitope (phosphorylated serines 396 and 404) as evidenced by Western blot (Fig. $3 A, B$ ) and by immunohistochemistry (Fig. $3 C-E)$. The hyperphosphorylation detected in the hippocampus of Tet/GSK- $3 \beta$ mice with the AD2 antibody, which recognizes an epitope similar to PHF-1 (phosphorylated serine 396), was also reverted in Gene-OFF Tet/GSK-3 $\beta$ mice as observed both by Western blot and by immunohistochemistry (Fig. 3A,B) (data not shown). We also analyzed the AT- 8 phosphoepitope (phosphorylated Ser202 and Thr205), an early marker of tau pathology in AD (Maurage et al., 2003), which is also phosphorylated by GSK-3 (Wang et al., 1998). As shown in Figure 3, $A$ and $B$, 
A
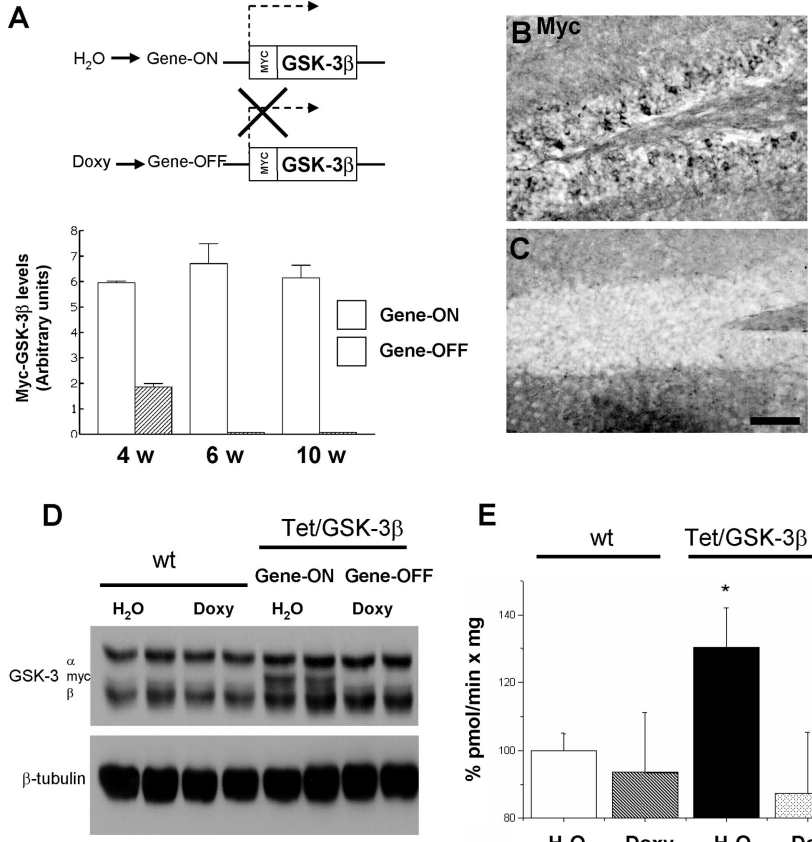

E

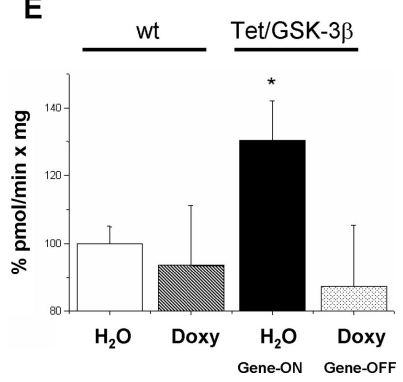

A

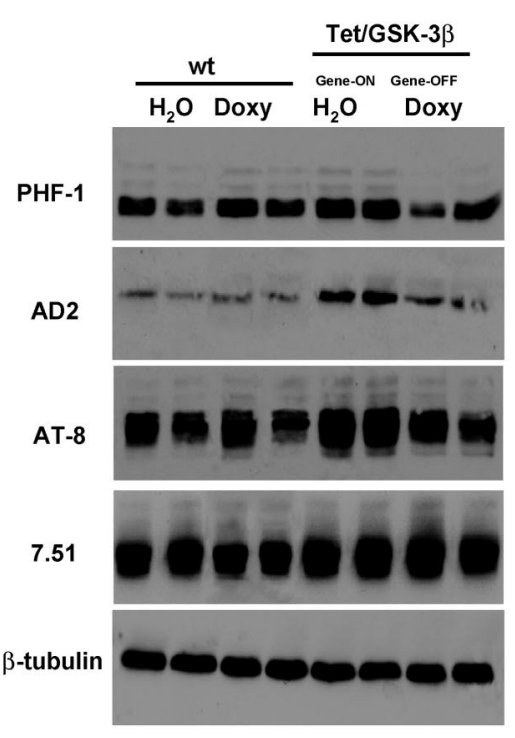

Gene-ON

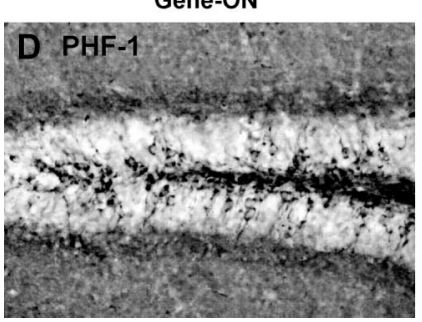

B

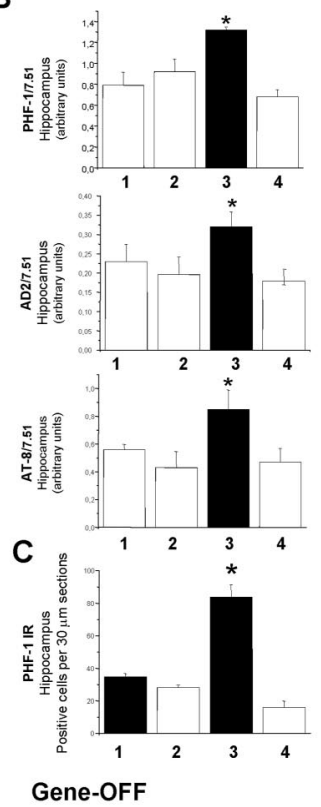

Figure 2. Transgene shutdown by doxycycline administration to Tet/GSK-3 $\beta$ mice. A, Schematic representation of GSK-3 $\beta$ transgene expression in untreated mice $\left(\mathrm{H}_{2} \mathrm{O}\right)$ and transgene shutdown by doxycycline (Doxy) administration. Quantification of GSK-3 $\beta$ transgenic protein levels after 4,6 , and 10 weeks of doxycycline treatment. B, C, Immunohistochemistry in hippocampal sections performed with the anti-Myc antibody in 10week-old Gene-ON Tet/GSK-3 $\beta$ mice $(\boldsymbol{B})$ and in 10-week-old Gene-0FF Tet/GSK-3 $\beta$ mice after 6 weeks of doxycycline treatment (C). D, Western blot analysis with an antibody against GSK-3 that recognizes the $\alpha$ and the $\beta$ endogenous isoforms as well as the Myc-tagged transgenic GSK-3 in 10-week-old wild-type (wt) and Tet/GSK-3 $\beta$ mice either untreated $\left(\mathrm{H}_{2} \mathrm{O}\right)$ or that received doxycycline during the last 6 weeks (Doxy). $\boldsymbol{E}$, Histogram showing comparison of GSK-3 activity in hippocampal homogenates from 10-week-old wt or Tet/GSK-3 $\beta$ mice, either untreated $\left(\mathrm{H}_{2} \mathrm{O}\right)$ or that received doxycycline during the last 6 weeks (Doxy). Error bars indicate SE. ${ }^{*} p<0.04$. Scale bar, $50 \mu \mathrm{m}$.

Gene-ON Tet/GSK- $3 \beta$ mice showed an increase in tau phosphorylation at the AT- 8 epitope. This AT-8 hyperphosphorylation was reverted to wild-type levels in the Gene-OFF Tet/ GSK-3 $\beta$ mice as demonstrated by Western blot and immunohistochemistry (Fig. $3 A, B$ ) (data not shown).

\section{Microtubule binding and stabilization ability of tau are restored in Gene-OFF Tet/GSK-3 $\beta$ mice}

It is well known that phosphorylated tau has a reduced affinity for microtubules and a reduced ability to promote microtubule assembly (Lindwall and Cole, 1984; Lu and Wood, 1993). This has also been proven both in in vitro assays and in transfected cells with tau phosphorylated by GSK-3 (Lovestone et al., 1996). In good agreement, we have previously shown that tau hyperphosphorylation in Tet/GSK-3 $\beta$ mice correlates with somatodendritic accumulation of microtubule-unbound tau in hippocampal neurons (Lucas et al., 2001). This was evidenced by immunohistochemistry with the 7.51 antibody that recognizes the microtubule binding domain of tau and that, accordingly, detects only unbound tau (Novak et al., 1991). We therefore decided to test whether somatodendritic accumulation of microtubuleunbound tau in hippocampal neurons of Tet/GSK-3 $\beta$ mice was also reversible after restoration of normal GSK-3 levels. For this, we performed immunohistochemistry with the 7.51 antibody on brain sections from Gene-ON and Gene-OFF Tet/GSK-3 $\beta$ mice

Figure 3. Reversal of Tau hyperphosphorylation in doxycycline-treated (Gene-OFF) Tet/ GSK-3 $\beta$ mice. $A$, Western blot analysis of hippocampal protein extracts from 10-week-old wild-type (wt), or Tet/GSK-3 $\beta$ mice, either untreated $\left(\mathrm{H}_{2} \mathrm{O}\right)$ or that received doxycycline during the last 6 weeks (Doxy) probed with the following anti-phospho-tau antibodies: PHF-1, AD2, and AT-8; and with the 7.51 antibody (total tau). B, C, Histograms showing the level of tau phosphorylation detected by Western blot with PHF-1, AD2, and AT-8 antibodies $(\boldsymbol{B})$ or by immunohistochemistry with the PHF-1 antibody (C). Samples were prepared from untreated wild-type (1) or Tet/GSK-3 $\beta$ (3) mice and from treated (doxycycline for 6 weeks) wild-type (2) or Tet/GSK-3 $\beta$ (4) mice. ${ }^{*} p<0.01$. Error bars indicate SE. $\boldsymbol{D}, \boldsymbol{E}$, Immunohistochemistry of hippocampal brain sections from Gene-ON and Gene-OFF Tet/GSK-3 $\beta$ mice performed with the PHF-1 antibody. Scale bar, $50 \mu \mathrm{m}$.

(Fig. 4A-D,F). As previously reported, 7.51-immunopositive neurons were abundant in the dentate gyrus of Gene-ON Tet/ GSK- $3 \beta$ mice (fivefold increase with respect to wild-type mice) (Fig. 4A, B,F). Interestingly, Gene-OFF Tet/GSK-3 $\beta$ mice showed a number of 7.51-immunopositive neurons similar to that found in wild-type mice (Fig. $4 D, F$ ).

We then wondered whether the increase in unbound tau in Tet/GSK-3 $\beta$ mice correlates with a reduced ability to promote microtubule assembly and, if so, whether this could be reverted by restoring normal GSK-3 levels. For this, we performed experiments of in vitro polymerization of tubulin with hippocampal homogenates from wild-type, Gene-ON Tet/GSK-3 $\beta$, and GeneOFF Tet/GSK- $3 \beta$ mice (Fig. $4 E, G$ ). After GTP induced polymerization of tubulin from hippocampal homogenates and subsequent centrifugation, the amount of polymerized microtubules was significantly lower in Gene-ON Tet/GSK- $3 \beta$ samples compared with wild-type and Gene-OFF Tet/GSK-3 $\beta$ ones. This was evident in the total amount of protein in the pellet and confirmed by Western blot with anti- $\beta$-tubulin antibody ( $35 \pm 4 \%$ reduction; $p<0.001$ ) (Fig. $4 E, G$ ). 

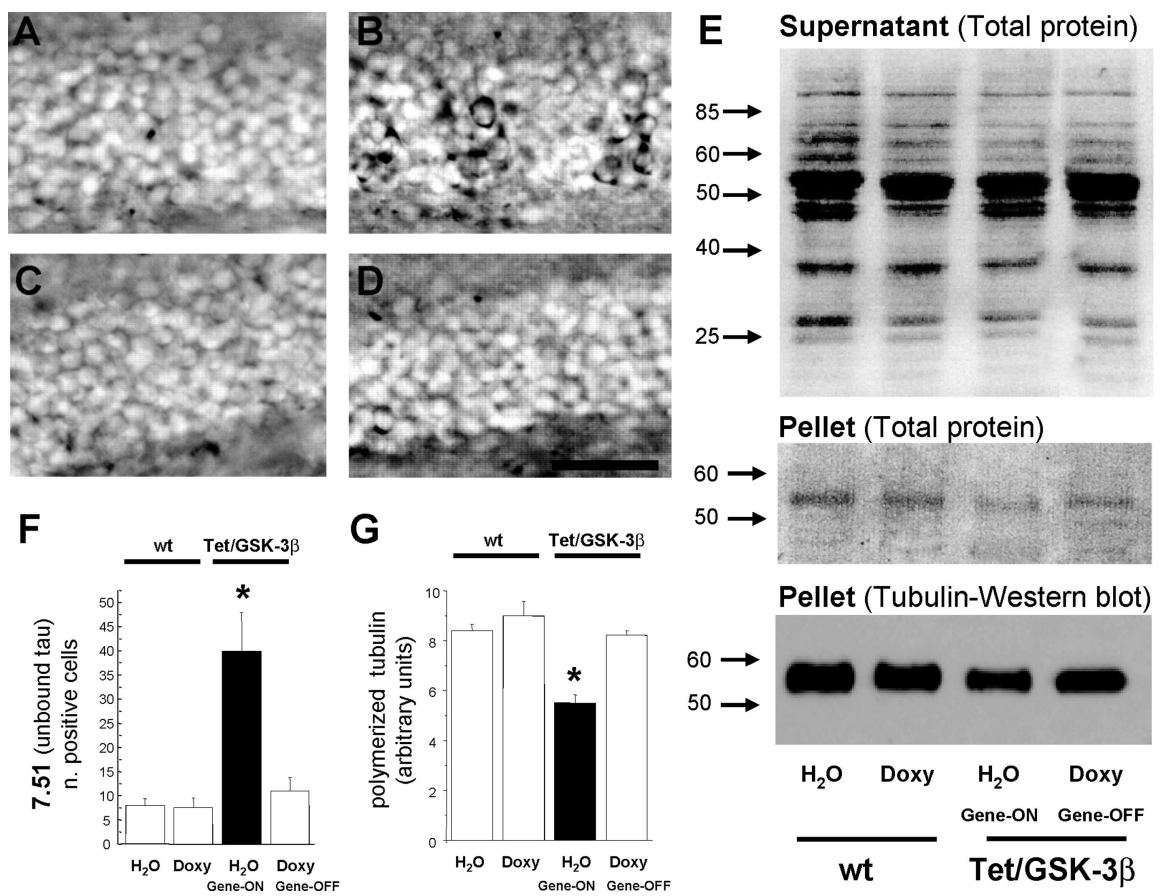

Figure 4. Reduced capacity of tau from Tet/GSK-3 $\beta$ mice to promote microtubule polymerization. Immunohistochemistry analysis of hippocampal brain sections from untreated wild-type $(\boldsymbol{A})$, Gene-ON Tet/GSK-3 $\beta(\boldsymbol{B})$, doxycycline-treated wild-type $(\boldsymbol{C})$, and Gene-OFF Tet/GSK-3 $\beta$ (D) mice performed with the 7.51 antibody. $\boldsymbol{E}$ shows total protein in supernatant and in pellet fractions after one cycle of polymerization of tubulin from hippocampus of wild-type (wt) or Tet/GSK-3 $\beta$ mice, either untreated $\left(\mathrm{H}_{2} \mathrm{O}\right)$ or that received doxycycline during the last 6 weeks (Doxy). The bottom panel shows levels of tubulin in the pellet samples analyzed by Western blot with an antibody against $\beta$-tubulin. $\boldsymbol{F}$, Histogram showing the number of 7.51-immunopositive neurons in the dentate gyrus of the mice shown in $\boldsymbol{A}-\boldsymbol{D}$. $\mathbf{G}$, Histogram showing the quantification of the levels of polymerized tubulin from the hippocampus of the different mouse groups shown in $\boldsymbol{E}$. Error bars indicate SE. ${ }^{*} p<0.001$. Scale bar, $200 \mu \mathrm{m}$.

\section{Gene-ON}

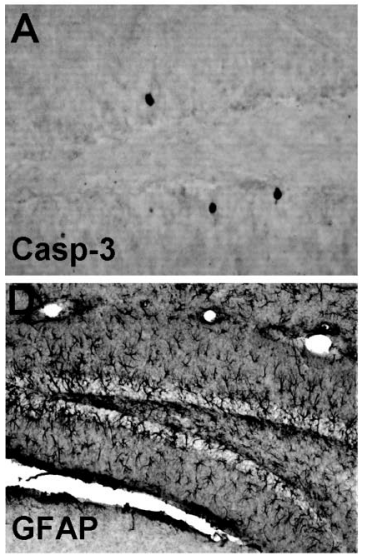

\section{Gene-OFF}

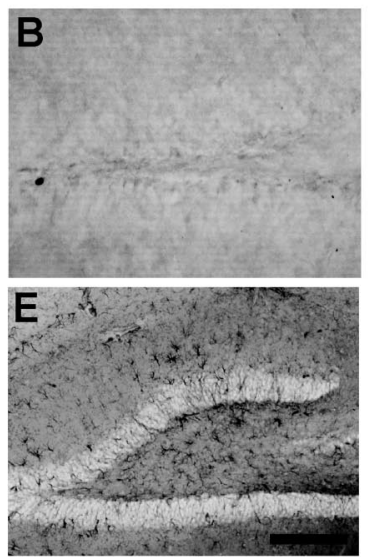

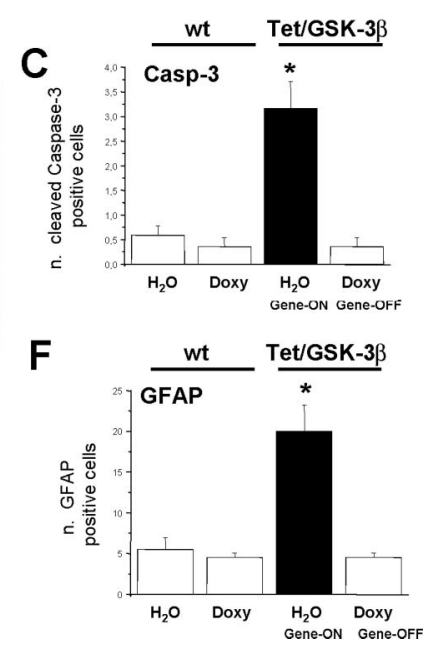

Figure 5. Reversal of apoptosis and reactive astrocytosis in doxycycline-treated (Gene-OFF) Tet/GSK-3 $\beta$ mice. Immunohistochemistry analysis of hippocampal brain sections from Gene-0N and Gene-0FF Tet/GSK-3 $\beta$ mice performed with the Casp-3 $(\boldsymbol{A}, \boldsymbol{B})$ and GAFP $(\boldsymbol{D}, \boldsymbol{E})$ antibodies. Quantification of the number of cleaved caspase-3-positive neurons $(\boldsymbol{C})$ and of reactive astrocytes $(\boldsymbol{F})$ in 10-week-old wild-type (wt) or Tet/GSK-3 $\beta$ mice, either untreated $\left(\mathrm{H}_{2} \mathrm{O}\right)$ or that received doxycycline during the last 6 weeks (Doxy). ${ }^{*} p<0.001$ in $C ;{ }^{*} p<0.001$ in $\boldsymbol{F}$. Error bars indicate SE. Scale bar, $50 \mu \mathrm{m}$.

Reversal of neuronal death and reactive gliosis in the hippocampus of Gene-OFF Tet/GSK-3 $\beta$ mice

As shown in Figure 1 and in the initial characterization of Tet/ GSK-3 $\beta$ mice (Lucas et al., 2001), overexpression of GSK-3 $\beta$ results in apoptotic neuronal death and reactive astrocytosis in the dentate gyrus of Tet/GSK- $3 \beta$ mice. Interestingly, 6 weeks of transgene shutdown resulted in full reversal of the neuronal ap- optosis phenotype as evidenced by immunohistochemical detection of cleaved caspase-3 (Fig. 5A-C). Similarly, the reactive astrocytosis observed in Gene-ON Tet/GSK- $3 \beta$ mice fully reverted in the doxycycline-treated (Gene-OFF) Tet/ GSK- $3 \beta$ mice as shown by immunohistochemistry performed with an antibody raised against GFAP (Fig. 5D-F).

\section{Rescue of spatial memory impairment in Gene-OFF Tet/GSK-3 $\beta$ mice}

Apart from the above-described cellular and biochemical alterations attributable to hippocampal overexpression of GSK-3 $\beta$, Tet/GSK- $3 \beta$ mice also show spatial memory deficit in the Morris water maze test (Lucas et al., 2001) and in the object recognition test (Fig. 1C). To determine whether restoration of normal GSK-3 activity also reverts the spatial memory deficit, we performed the object recognition test with Gene-ON and Gene-OFF Tet/ GSK-3 $\beta$ mice as well as with wild-type mice with equivalent water or doxycycline paradigms. As shown in Figure 6, the doxycycline treatment did not affect the performance of wild-type mice. However, it significantly improved the performance of Gene-OFF Tet/GSK- $3 \beta$ mice, thus rendering them indistinguishable from their control wild-type littermates.

\section{Discussion}

Neuronal dysregulation of GSK-3 has been proposed to be a key mediator of $\mathrm{AD}$ pathogenesis (Avila et al., 2004). Here, by using the conditional mouse model Tet/ GSK-3 $\beta$ (Lucas et al., 2001), we show that tau hyperphosphorylation, apoptotic neuronal death, and cognitive deficit attributable to increased hippocampal GSK-3 activity can be completely reverted by the restoration of normal GSK-3 activity by silencing of transgene expression.

Dysregulation of GSK-3 has been linked to several prevalent pathological conditions apart from AD. These include diabetes and/or insulin resistance (EldarFinkelman, 2002), muscle hypertrophy (Hardt and Sadoshima, 2002), cancer (Manoukian and Woodgett, 2002), bipolar mood disorder (Klein and Melton, 1996), schizophrenia (Kozlovsky et al., 2002), and other neurodegenerative diseases like Huntington's disease (Carmichael et al., 2002; Berger et al., 2005) and frontotemporal dementia with parkinsonism linked to chromosome 17 (Engel et al., 2005). Therefore, the data reported here on reversibility of alterations secondary to increased GSK-3 activity may have implications in many disease conditions other than $\mathrm{AD}$.

The ability to silence transgene expression in adult symptomatic Tet/GSK- $3 \beta$ mice can be very useful when testing the new 


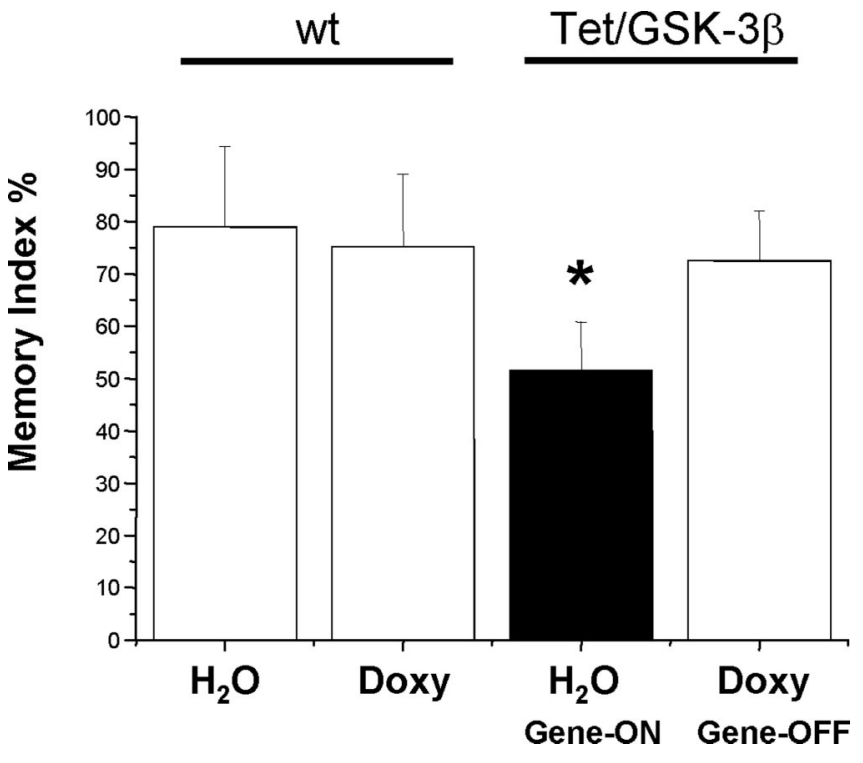

Figure 6. Reversal of spatial memory deficit in doxycycline-treated (Gene-OFF) Tet/GSK-3 $\beta$ mice. Histogram showing the performance of 10-week-old wild-type (wt) or Tet/GSK-3 $\beta$ mice, either untreated $\left(\mathrm{H}_{2} \mathrm{O}\right)$ or that received doxycycline during the last 6 weeks (Doxy) in the object recognition test. The memory index is expressed as exploratory preference in the retention test. Memory index $=\left[t_{C} /\left(t_{\mathrm{A}}+t_{\mathrm{C}}\right)\right] \times 100$, with $\mathrm{A}$ and $\mathrm{C}$ representing the familiar and the novel objects, respectively. Error bars indicate SE. ${ }^{*} p<0.05$.

and selective GSK-3 inhibitors that pharmaceutical companies are currently developing in view of the increasing evidence supporting the GSK-3 deregulation in $\mathrm{AD}$ and other mentioned chronic conditions (Cross et al., 2001; Eldar-Finkelman, 2002; Martinez et al., 2002; Bhat et al., 2004; Cohen and Goedert, 2004). In this regard, the efficacy of different concentrations of GSK-3 inhibitors given to Tet/GSK-3 $\beta$ mice can be compared with the restoration of normal GSK-3 levels and activity achieved by giving the tetracycline analog doxycycline to the mice.

Aberrant intraneuronal protein deposits are a common feature for many neurodegenerative diseases such as tauopathies, Parkinson's disease, and Huntington's disease. Whether these inclusion bodies are a common pathogenic mechanism for all of these diseases (Price et al., 1998; Tobin and Signer, 2000) or a defense mechanism as recently proposed for the intracellular aggregates in Huntington's disease (Arrasate et al., 2004) is still a matter of debate. In this regard, we have previously shown in a similar conditional mouse model of Huntington's disease that non-amyloid-like inclusions are fully reversible and that motor symptoms are susceptible to revert both in early stages (Yamamoto et al., 2000) and also late in the course after detectable neuronal death and after formation of irreversible amyloid-like inclusions (Diaz-Hernandez et al., 2005). The fact that the Tet/GSK-3 $\beta$ mice show neuropathology and cognitive impairment without the formation of tau filaments (Hernandez et al., 2002) also argues against tau aggregates as a key pathogenic agent. Because here we found reversible somatodendritic accumulation of unbound tau and decreased microtubule stabilization capacity in Tet/GSK-3 $\beta$ mice, it seems that destabilization of microtubules might be responsible for the AD-like phenotype in the absence of tau aggregation. In good agreement, it has been recently shown in mice that conditionally overexpress FTDP-17 human mutant tau ${ }^{\text {P301L }}$ (Santacruz et al., 2005) that brain weight loss and cognitive deficit depend on transgene expression but not on tau filament formation, because these mice recovered spatial memory when silencing transgene expression but did not prevent the development of neurofibrillary tangles.
Regardless of the controversial role of aberrant proteinaceous aggregates in neurodegenerative diseases, because increased GSK-3 activity has been postulated in AD and related tauopathies, our here reported reversal of neuropathology and learning deficit after restoration of normal GSK-3 levels and activity strongly supports the notion that GSK-3 inhibitors might be useful for reversing $\mathrm{AD}$ neuropathology and symptoms. In this regard, it has been reported that administration of pharmacological GSK-3 inhibitors to mouse models of tauopathy results not only in decreased tau aggregation (Perez et al., 2003; Noble et al., 2005) but also in decreased neurodegeneration (Noble et al., 2005).

It has been reported previously that GSK- $3 \beta$ engages in a positive feedback loop with protein phosphatase 1 (PP1) (Jope, 2003; Zhang et al., 2003). This takes place through GSK-3 $\beta$-mediated increase in PP1 I2 (inhibitor 2) phosphorylation, PP1 activation, PP1-mediated dephosphorylation of GSK-3 $\beta$ at the Ser9 inhibitory phospho-residue, and additional activation of GSK-3 $\beta$. Inhibition of GSK-3 by a long treatment with a low dose of the nonselective GSK-3 inhibitor lithium (below the $K_{\mathrm{i}}$ for inhibition) is supposed to occur through this amplification loop (Jope, 2003; Zhang et al., 2003). More recently, this positive forward loop has also been demonstrated to amplify activation of GSK-3 on stimulation of N2R-NMDA receptors in cultured neurons (Szatmari et al., 2005). We wondered whether chronic activation of GSK-3 in Tet/GSK-3 $\beta$ mice might activate this loop to a level that would maintain GSK-3 activity elevated regardless of restoration of normal GSK-3 levels. Because 6 weeks of transgene shutdown results in normal GSK-3 levels and activity, it seems that the amplification loop does not continue working after cessation of its trigger.

In summary, the data presented here strongly support the notion that GSK-3 is a good therapeutic target for AD and suggest that Tet/GSK-3 $\beta$ mice can be a useful tool to evaluate the efficacy of selective inhibitors that are currently under development by monitoring their effects in parallel to restoration of normal GSK-3 levels and activity by transgene shutdown.

\section{References}

Alvarez G, Munoz-Montano JR, Satrustegui J, Avila J, Bogonez E, Diaz-Nido J (1999) Lithium protects cultured neurons against beta-amyloidinduced neurodegeneration. FEBS Lett 453:260-264.

Arrasate M, Mitra S, Schweitzer ES, Segal MR, Finkbeiner S (2004) Inclusion body formation reduces levels of mutant huntingtin and the risk of neuronal death. Nature 431:805-810.

Avila J, Lucas JJ, Perez M, Hernandez F (2004) Role of tau protein in both physiological and pathological conditions. Physiol Rev 84:361-384.

Berger Z, Ttofi EK, Michel CH, Pasco M, Tenant S, Rubinsztein DC, O’Kane CJ (2005) Lithium rescues toxicity of aggregate-prone proteins in Drosophila by perturbing Wnt pathway. Hum Mol Genet 14:3003-3011.

Bhat RV, Budd Haeberlein SL, Avila J (2004) Glycogen synthase kinase 3: a drug target for CNS therapies. J Neurochem 89:1313-1317.

Biernat J, Mandelkow EM, Schroter C, Lichtenberg-Kraag B, Steiner B, Berling B, Meyer H, Mercken M, Vandermeeren A, Goedert M, Mandelkow E (1992) The switch of tau protein to an Alzheimer-like state includes the phosphorylation of two serine-proline motifs upstream of the microtubule binding region. EMBO J 11:1593-1597.

Buee-Scherrer V, Condamines O, Mourton-Gilles C, Jakes R, Goedert M, Pau B, Delacourte A (1996) AD2, a phosphorylation-dependent monoclonal antibody directed against tau proteins found in Alzheimer's disease. Brain Res Mol Brain Res 39:79-88.

Busciglio J, Lorenzo A, Yeh J, Yankner BA (1995) $\beta$-Amyloid fibrils induce tau phosphorylation and loss of microtubule binding. Neuron 14:879-888.

Carmichael J, Sugars KL, Bao YP, Rubinsztein DC (2002) Glycogen synthase kinase-3beta inhibitors prevent cellular polyglutamine toxicity caused by the Huntington's disease mutation. J Biol Chem 277:33791-33798.

Cohen P, Goedert M (2004) GSK3 inhibitors: development and therapeutic potential. Nat Rev Drug Discov 3:479-487.

Cross DA, Culbert AA, Chalmers KA, Facci L, Skaper SD, Reith AD (2001) 
Selective small-molecule inhibitors of glycogen synthase kinase- 3 activity protect primary neurones from death. J Neurochem 77:94-102.

Diaz-Hernandez M, Torres-Peraza J, Salvatori-Abarca A, Moran MA, Gomez-Ramos P, Alberch J, Lucas JJ (2005) Full motor recovery despite striatal neuron loss and formation of irreversible amyloid-like inclusions in a conditional mouse model of Huntington's disease. J Neurosci 25:9773-9781.

Eldar-Finkelman H (2002) Glycogen synthase kinase 3: an emerging therapeutic target. Trends Mol Med 8:126-132.

Engel T, Lucas JJ, Gomez-Ramos P, Moran MA, Avila J, Hernandez F (2005) Cooexpression of FTDP-17 tau and GSK-3beta in transgenic mice induce tau polymerization and neurodegeneration. Neurobiol Aging, in press.

Ennaceur A, Neave N, Aggleton JP (1997) Spontaneous object recognition and object location memory in rats: the effects of lesions in the cingulate cortices, the medial prefrontal cortex, the cingulum bundle and the fornix. Exp Brain Res 113:509-519.

Ferreira A, Lu Q, Orecchio L, Kosik KS (1997) Selective phosphorylation of adult tau isoforms in mature hippocampal neurons exposed to fibrillar A beta. Mol Cell Neurosci 9:220-234.

Goedert M, Jakes R, Vanmechelen E (1995) Monoclonal antibody AT8 recognises tau protein phosphorylated at both serine 202 and threonine 205. Neurosci Lett 189:167-169.

Greenberg SG, Davies P, Schein JD, Binder LI (1992) Hydrofluoric acidtreated tau PHF proteins display the same biochemical properties as normal tau. J Biol Chem 267:564-569.

Hardt SE, Sadoshima J (2002) Glycogen synthase kinase-3beta: a novel regulator of cardiac hypertrophy and development. Circ Res 90:1055-1063.

Hernandez F, Borrell J, Guaza C, Avila J, Lucas JJ (2002) Spatial learning deficit in transgenic mice that conditionally over-express GSK-3beta in the brain but do not form tau filaments. J Neurochem 83:1529-1533.

Hong M, Chen DC, Klein PS, Lee VM (1997) Lithium reduces tau phosphorylation by inhibition of glycogen synthase kinase-3. J Biol Chem 272:25326-25332.

Jope RS (2003) Lithium and GSK-3: one inhibitor, two inhibitory actions, multiple outcomes. Trends Pharmacol Sci 24:441-443.

Jope RS, Johnson GV (2004) The glamour and gloom of glycogen synthase kinase-3. Trends Biochem Sci 29:95-102.

Klein PS, Melton DA (1996) A molecular mechanism for the effect of lithium on development. Proc Natl Acad Sci USA 93:8455-8459.

Kozlovsky N, Belmaker RH, Agam G (2002) GSK-3 and the neurodevelopmental hypothesis of schizophrenia. Eur Neuropsychopharmacol 12:13-25.

Lindwall G, Cole RD (1984) Phosphorylation affects the ability of tau protein to promote microtubule assembly. J Biol Chem 259:5301-5305.

Lovestone S, Reynolds CH, Latimer D, Davis DR, Anderton BH, Gallo JM, Hanger D, Mulot S, Marquardt B, Stabel S, Woodgett JR, Miller CCJ (1994) Alzheimer's disease-like phosphorylation of the microtubuleassociated protein tau by glycogen synthase kinase-3 in transfected mammalian cells. Curr Biol 4:1077-1086.

Lovestone S, Hartley CL, Pearce J, Anderton BH (1996) Phosphorylation of tau by glycogen synthase kinase- 3 beta in intact mammalian cells: the effects on the organization and stability of microtubules. Neuroscience 73:1145-1157.

Lu Q, Wood JG (1993) Functional studies of Alzheimer's disease tau protein. J Neurosci 13:508-515.

Lucas JJ, Hernandez F, Gomez-Ramos P, Moran MA, Hen R, Avila J (2001) Decreased nuclear beta-catenin, tau hyperphosphorylation and neurodegeneration in GSK-3beta conditional transgenic mice. EMBO J 20:27-39.

Manoukian AS, Woodgett JR (2002) Role of glycogen synthase kinase-3 in cancer: regulation by Wnts and other signaling pathways. Adv Cancer Res 84:203-229.

Martinez A, Alonso M, Castro A, Perez C, Moreno FJ (2002) First non-ATP competitive glycogen synthase kinase 3 beta (GSK-3beta) inhibitors: thiadiazolidinones (TDZD) as potential drugs for the treatment of Alzheimer's disease. J Med Chem 45:1292-1299.

Maurage CA, Sergeant N, Ruchoux MM, Hauw JJ, Delacourte A (2003) Phosphorylated serine 199 of microtubule-associated protein tau is a neuronal epitope abundantly expressed in youth and an early marker of tau pathology. Acta Neuropathol (Berl) 105:89-97.

Mercken M, Vandermeeren M, Lubke U, Six J, Boons J, Van de Voorde A, Martin JJ, Gheuens J (1992) Monoclonal antibodies with selective specificity for Alzheimer Tau are directed against phosphatase-sensitive epitopes. Acta Neuropathol (Berl) 84:265-272.
Moreno FJ, Munoz-Montano JR, Avila J (1996) Glycogen synthase kinase 3 phosphorylation of different residues in the presence of different factors: analysis on tau protein. Mol Cell Biochem 165:47-54.

Munoz-Montano JR, Moreno FJ, Avila J, Diaz-Nido J (1997) Lithium inhibits Alzheimer's disease-like tau protein phosphorylation in neurons. FEBS Lett 411:183-188.

Noble W, Planel E, Zehr C, Olm V, Meyerson J, Suleman F, Gaynor K, Wang L, LaFrancois J, Feinstein B, Burns M, Krishnamurthy P, Wen Y, Bhat R, Lewis J, Dickson D, Duff K (2005) Inhibition of glycogen synthase kinase-3 by lithium correlates with reduced tauopathy and degeneration in vivo. Proc Natl Acad Sci USA 102:6990-6995.

Novak M, Jakes R, Edwards PC, Milstein C, Wischik CM (1991) Difference between the tau protein of Alzheimer paired helical filament core and normal tau revealed by epitope analysis of monoclonal antibodies 423 and 7.51. Proc Natl Acad Sci USA 88:5837-5841.

Otvos Jr L, Feiner L, Lang E, Szendrei GI, Goedert M, Lee VM (1994) Monoclonal antibody PHF-1 recognizes tau protein phosphorylated at serine residues 396 and 404. J Neurosci Res 39:669-673.

Paxinos G, Franklin KBJ (2001) The mouse brain in stereotaxic coordinates, Ed 2. San Diego: Academic.

Pei JJ, Braak E, Braak H, Grundke-Iqbal I, Iqbal K, Winblad B, Cowburn RF (1999) Distribution of active glycogen synthase kinase 3beta (GSK3beta) in brains staged for Alzheimer disease neurofibrillary changes. J Neuropathol Exp Neurol 58:1010-1019.

Perez M, Hernandez F, Lim F, Diaz-Nido J, Avila J (2003) Chronic lithium treatment decreases mutant tau protein aggregation in a transgenic mouse model. J Alzheimers Dis 5:301-308.

Phiel CJ, Wilson CA, Lee VM, Klein PS (2003) GSK-3alpha regulates production of Alzheimer's disease amyloid-beta peptides. Nature 423:435-439.

Price DL, Sisodia SS, Borchelt DR (1998) Genetic neurodegenerative diseases: the human illness and transgenic models. Science 282:1079-1083.

Ryder J, Su Y, Liu F, Li B, Zhou Y, Ni B (2003) Divergent roles of GSK3 and CDK5 in APP processing. Biochem Biophys Res Commun 312:922-929.

Santacruz K, Lewis J, Spires T, Paulson J, Kotilinek L, Ingelsson M, Guimaraes A, DeTure M, Ramsden M, McGowan E, Forster C, Yue M, Orne J, Janus C, Mariash A, Kuskowski M, Hyman B, Hutton M, Ashe KH (2005) Tau suppression in a neurodegenerative mouse model improves memory function. Science 309:476-481.

Scheele RB, Borisy GG (1976) Comparison of the sedimentation properties of microtubule protein oligomers prepared by two different procedures. Biochem Biophys Res Commun 70:1-7.

Shelanski ML, Gaskin F, Cantor CR (1973) Microtubule assembly in the absence of added nucleotides. Proc Natl Acad Sci USA 70:765-768.

Shiurba RA, Ishiguro K, Takahashi M, Sato K, Spooner ET, Mercken M, Yoshida R, Wheelock TR, Yanagawa H, Imahori K, Nixon RA (1996) Immunocytochemistry of tau phosphoserine 413 and tau protein kinase I in Alzheimer pathology. Brain Res 737:119-132.

Spittaels K, Van den Haute C, Van Dorpe J, Geerts H, Mercken M, Bruynseels K, Lasrado R, Vandezande K, Laenen I, Boon T, Van Lint J, Vandenheede J, Moechars D, Loos R, Van Leuven F (2000) Glycogen synthase kinase3beta phosphorylates protein tau and rescues the axonopathy in the central nervous system of human four-repeat tau transgenic mice. J Biol Chem 275:41340-41349.

Stambolic V, Woodgett JR (1994) Mitogen inactivation of glycogen synthase kinase- 3 beta in intact cells via serine 9 phosphorylation. Biochem J 303:701-704.

Sun X, Sato S, Murayama O, Murayama M, Park JM, Yamaguchi H, Takashima A (2002) Lithium inhibits amyloid secretion in COS7 cells transfected with amyloid precursor protein C100. Neurosci Lett 321:61-64.

Szatmari E, Habas A, Yang P, Zheng JJ, Hagg T, Hetman M (2005) A positive feedback loop between glycogen synthase kinase 3 beta and protein phosphatase 1 after stimulation of NR2B NMDA receptors in forebrain neurons. J Biol Chem 280:37526-37535.

Takashima A, Noguchi K, Sato K, Hoshino T, Imahori K (1993) Tau protein kinase I is essential for amyloid beta-protein-induced neurotoxicity. Proc Natl Acad Sci USA 90:7789-7793.

Takashima A, Noguchi K, Michel G, Mercken M, Hoshi M, Ishiguro K, Imahori K (1996) Exposure of rat hippocampal neurons to amyloid beta peptide (25-35) induces the inactivation of phosphatidyl inositol-3 kinase and the activation of tau protein kinase I/glycogen synthase kinase-3 beta. Neurosci Lett 203:33-36. 
Takashima A, Murayama M, Murayama O, Kohno T, Honda T, Yasutake K, Nihonmatsu N, Mercken M, Yamaguchi H, Sugihara S, Wolozin B (1998) Presenilin 1 associates with glycogen synthase kinase-3beta and its substrate tau. Proc Natl Acad Sci USA 95:9637-9641.

Tobin AJ, Signer ER (2000) Huntington's disease: the challenge for cell biologists. Trends Cell Biol 10:531-536.

Torreilles F, Roquet F, Granier C, Pau B, Mourton-Gilles C (2000) Binding specificity of monoclonal antibody AD2: influence of the phosphorylation state of tau. Brain Res Mol Brain Res 78:181-185.

Wang JZ, Wu Q, Smith A, Grundke-Iqbal I, Iqbal K (1998) Tau is phosphorylated by GSK-3 at several sites found in Alzheimer disease and its biological activity markedly inhibited only after it is prephosphorylated by A-kinase. FEBS Lett 436:28-34.

Woodgett JR (1990) Molecular cloning and expression of glycogen synthase kinase-3/factor A. EMBO J 9:2431-2438.
Woolley ML, Marsden CA, Sleight AJ, Fone KC (2003) Reversal of a cholinergic-induced deficit in a rodent model of recognition memory by the selective 5-HT6 receptor antagonist, Ro 04-6790. Psychopharmacology (Berl) 170:358-367.

Yamamoto A, Lucas JJ, Hen R (2000) Reversal of neuropathology and motor dysfunction in a conditional model of Huntington's disease. Cell 101:57-66.

Zhang F, Phiel CJ, Spece L, Gurvich N, Klein PS (2003) Inhibitory phosphorylation of glycogen synthase kinase-3 (GSK-3) in response to lithium. Evidence for autoregulation of GSK-3. J Biol Chem 278:33067-33077.

Zhang Z, Hartmann H, Do VM, Abramowski D, Sturchler-Pierrat C, Staufenbiel M, Sommer B, van de Wetering M, Clevers H, Saftig P, De Strooper B, He X, Yankner BA (1998) Destabilization of beta-catenin by mutations in presenilin-1 potentiates neuronal apoptosis. Nature 395:698-702. 